\title{
Anatomical characterization of Passiflora cincinnata Mast. fruit subjected to refrigeration
}

\author{
Carolina Rodrigues Victor de Carvalho ${ }^{1}$, Ana Maria Mapeli², Andreia Barroncas de Oliveira ${ }^{3}$
}

\begin{abstract}
Passiflora cincinnata is a species of wild passion fruit whose fruit has potential for use by the food industry. In this context, an anatomical study of the pericarp may help in understanding the changes which occur during the postharvest period. The objective of this work was to anatomically characterize the $P$. cincinnata pericarp, focusing on the structural changes which occur during refrigerated storage. The selected fruits were kept in net-like packaging at $5^{\circ} \mathrm{C}$ and evaluated every 15 days for a period of 90 days. Pericarp samples were hand cut on these dates for structural description and to detect starch, phenolic compounds, alkaloids, polysaccharides, proteins, lipids and lignin through histochemical tests. Other samples were analyzed by scanning electron microscope. The fruit is composed of three anatomically distinct regions: exocarp, mesocarp and endocarp. The mesocarp stands out for the presence of sclerified cells and the lax parenchyma, which increased its number of layers during the evaluated period. Idioblasts with prismatic crystals, drusen, silica crystals and raphides were identified, but the amounts reduced over time. This reduction and enlargement of the lax parenchyma were the main changes observed in the postharvest period of $P$. cincinnata pericarps.
\end{abstract}

Index terms: Calcium oxalate crystals; wild passion fruit; postharvest; histochemical tests; silica.

\section{Caracterização anatômica do fruto de Passiflora cincinnata Mast. submetido à refrigeração}

\section{Corresponding author: carolcarv.93@gmail.com}

Received: August 15, 2020 Accepted: February 15, 2021

Copyright: All the contents of this journal, except where otherwise noted, is licensed under a Creative Commons Attribution License.

\section{(cc) $\mathbf{E Y}$}

Resumo - Passiflora cincinnata é uma espécie de maracujá silvestre cujo fruto possui potencial de uso pela indústria de alimentos. Neste contexto, o estudo anatômico do pericarpo pode ajudar na compreensão das mudanças que ocorrem durante o período pós-colheita. O objetivo deste trabalho foi caracterizar anatomicamente o pericarpo de $P$. cincinnata, com enfoque nas mudanças estruturais que ocorrem durante o armazenamento refrigerado. Os frutos selecionados foram mantidos em embalagens do tipo rede, a $5^{\circ} \mathrm{C}$, sendo realizadas avaliações a cada 15 dias, por um período de 90 dias. Nessas datas, amostras do pericarpo foram cortadas à mão para descrição estrutural e detecção de amido, compostos fenólicos, alcaloides, polissacarídeos, proteínas, lipídeos e lignina, através dos testes histoquímicos. Outras amostras foram analisadas no microscópio eletrônico de varredura. $O$ fruto é composto por três regiões anatomicamente distintas: exocarpo, mesocarpo e endocarpo. O mesocarpo destaca-se pela presença de células esclerificadas e do parênquima laxo, cujo número de camadas aumentou durante o período avaliado. Foram identificados idioblastos com cristais prismáticos, drusas, cristais de sílica e ráfides, cuja quantidade sofreu redução ao longo do tempo. Essa redução e o aumento do parênquima laxo foram as principais mudanças observadas no período pós-colheita do pericarpo de $P$. cincinnata.

Termos para indexação: Cristais de oxalato de cálcio; maracujá silvestre; pós-colheita; testes histoquímicos; sílica.

\footnotetext{
${ }^{1}$ Msc. in Enviromental Science. Researcher. Universidade Federal do Oeste da Bahia, Barreiras-Bahia, Brazil. E-mail: carolcarv.93@gmail.com ${ }^{\text {(ORCID }}$ 0000-0003-2259-5394)

${ }^{2} \mathrm{PhD}$ in Plant Physiology. Professor at the Universidade Federal do Oeste da Bahia, Barreiras-Bahia, Brazil. E-mail: mmapeli@ufob.edu.br. (ORCID: 0000-0002-6028-1989)

${ }^{3} \mathrm{PhD}$ in Botany. Professor at the Universidade Federal do Oeste da Bahia, Barreiras-Bahia, Brazil. E-mail: andreia.oliveira@ufob.edu.br ${ }^{\text {(ORCID }}$
} 0000-0001-5294-2882) 


\section{Introduction}

Passiflora L. is the largest genus in the Passifloraceae family (GURSKI, 2015). It is estimated that it has more than 500 species (ARAÚJO et al., 2008; MONTERO et al., 2016), distributed in tropical and subtropical regions (GURSKI, 2015). This genus is known to group species with economic importance, since some are grown as ornamental plants (DHAWAN et al., 2004; PEIXOTO, 2005), while others are known for their pharmacological properties (ZERAIK et al., 2010; COSTA, 2013; GAZOLA, 2014; ESTEVAM et al., 2017) or for their use in the food industry (OLIVEIRA et al., 2002; NASCIMENTO et al., 2013; ZERAIK et al., 2010; COSTA, 2013; SOUZA et al., 2008). However, the focus of academic studies is mainly directed to the Passiflora edulis species, known as yellow passion fruit, due to commercial demand (SANTOS et al., 2012).

Passiflora cincinnata Mast. is found in this genus, and is a species of wild passion fruit with wide geographical distribution in the Brazilian territory (Alagoas, Bahia, Ceará, Goiás, Mato Grosso, Mato Grosso do Sul, Minas Gerais, Pará, Paraíba, Pernambuco, Piauí, Rio Grande do Norte, Rio de Janeiro, São Paulo and the Federal District) and in other South American countries (Argentina, Bolivia, Colombia, Paraguay and Venezuela) (CERVI, 1997; GURSKI, 2015).

The aforementioned species has several popular regional names, such as: maracujá-mochila, maracujádo-mato, maracujá-tubarão, maracujá-brabo, maracujáde-casca-verde, flor-da-paixão, maracujá, maracujácultivado and maracujá-de-boi (CERVI, 1997; NUNES, 2002; OLIVEIRA; RUGGIERO, 2005), being described as a woody vine, generally entirely glabrous, rarely velvety-hairy, with cylindrical or subangular stem and simple leaves, 3-5 palmatipartites, dark green on the adaxial face and pale on the abaxial face (ARAÚJO, 2007). It presents pale pink to violet color and blue violet flowers, corolla with a purple base, lighter bands in the middle and blue-violet in the upper portion (ARAÚJO, 2007; GURSKI, 2015); glabrous ovary and berry type fruit, globose, dark green; containing ovate, cross-linked, foveolated seeds (NUNES, 2002) and with light yellow aryl (GURSKI, 2015).

Wild species such as $P$. cincinnata are threatened due to habitat fragmentation which has been occurring in the region in the Northeastern Semi-arid region; a fact which can lead to genetic diversity loss of the species, which supports the need for studies aiming at its description and evaluation (ARAÚJO et al., 2008). In addition, despite being a wild species, $P$. cincinnata fruit is already commercialized for both fresh consumption at local markets and for use in small processed food industries which use the pulp to produce sweets and jellies (etc.), due to its sui generis (unique) flavor which is characteristic of Cerrado fruits (ARAÚJO et al., 2008; SILVA et al., 2008; AZOUBEL et al., 2011; OLIVEIRA, 2014; SIEBRA et al., 2018).

However, although there is no information regarding the use of $P$. cincinnata pericarp by the population or by the food industry, data already exist which suggest its use in manufacturing flour which could be used for therapeutic purposes (PITA, 2012). According to Oliveira et al. (2002), the yellow passion fruit peels (Passiflora edulis f. Flavicarpa) are basically composed of carbohydrates, proteins and pectins, making it possible to use them in manufacturing sweets and flour, which already occurs with the yellow passion fruit pericarp (OLIVEIRA et al., 2002; ISHIMOTO et al., 2007; SOUZA et al., 2008). It is also worth noting that the use of passion fruit peel flour in diets can assist in treating diabetics and dyslipidemics due to its effect on glycemic control and LDL cholesterol control (SOUZA et al., 2008; PITA, 2012).

Furthermore, it is worth mentioning that adequate conservation of the fruit in the post-harvest period preserves the organoleptic properties and the nutritional quality of vegetables, which important aspects for the functionality of the food to remain viable after its processing (MDITSHWA et al., 2017). One of the techniques used in post-harvest conservation is refrigeration, which has already been shown to be efficient in preserving the physicochemical characteristics of passion fruit (CARVALHO, 2019). In this context, an anatomical study of the $P$. cincinnata pericarp can act as a useful tool in understanding both the senescence process of the fruit and the physiological changes which occur during the post-harvest period (ROCHA et al., 2010; LIMA et al., 2013), in addition to complementing the already-described anatomical data for the pericarp of this species (GURSKI, 2015).

It is worth remembering that the fruits of the Passiflora species still require further studies since they are not completely known or understood, and therefore experiments which find useful information to deepen the anatomical data of these plants, as well as to identify patterns and establish relationships between the characters and the environment are necessary for understanding and preserving these species, including $P$. cincinnata (GURSKI, 2015).

Thus, the objective of this work was to anatomically characterize $P$. cincinnata pericarp stored under refrigeration, focusing on structural changes which occur during its post-harvest period. 


\section{Material and methods}

\section{Fruit acquisition and experiment setup}

The experiment was conducted at the Center for the Recovery of Degraded Areas (CRAD) at the Campus Rector Edgard Santos, at the Federal University of Western Bahia (UFOB), in the municipality of Barreiras, Bahia. The $P$. cincinnata fruits came from the rural area of the municipality of Bonito, Bahia, (latitude $11.9475^{\circ} \mathrm{S}$, longitude $41.3210^{\circ} \mathrm{W}$ ) and acquired at a market in Barreiras, Bahia, in March 2019. Next, the fruits were visually selected for health, appearance and ripeness degree so as to use only healthy fruit and at the point of commercialization.

The selected fruits were weighed, packed in nettype packaging and stored in a cold chamber at $5{ }^{\circ} \mathrm{C}$, as this temperature has proven to be efficient for preserving the chemical and physical characteristics of $P$. cincinnata fruit (CARVALHO, 2019). Evaluations during storage were performed at 15-day intervals in the following order: day $0 ; 15 ; 30 ; 45 ; 60 ; 75$ and 90 . A total of 40 fruits were subjected to refrigeration and morphologically analyzed during the experiment, 14 of which (meaning 2 per evaluation interval) were used in the anatomical analysis.

The fruits were taken on these dates to the $U F O B$ Morpho-anatomy and Plant Physiology Laboratory where they were photographed for later morphological comparison. Samples were taken from the pericarp and fixed in $70 \%$ FAA (formaldehyde, acetic acid, 70\% ethanol) for 48 hours with the objective to paralyze the organ's metabolism, and subsequently submitted to $70 \%$ alcohol for conservation.

\section{Anatomical characterization}

Freehand cross-sections of the previously fixed fragments were made using a disposable blade and styrofoam as a support to structurally characterize the pericarp. The cuts resulting from this process were submitted to reagents of the histochemical tests. Some of these fixed material cuts were used as a negative control (white), so they were not subjected to these reagents. The following tests were carried out: potassium dichromate (Gabe, 1968) and iron chloride III (JOHANSEN, 1940) were used to detect general phenolic compounds, lugol was used to detect starch (JENSEN, 1962), Wagner (FURR and MAHLBERG, 1981) and Dittmar (FURR and MAHLBERG, 1981) reagents were used for alkaloids, Sudan III (JOHANSEN, 1940) was used to detect total lipids, Bromophenol Blue Mercury for protein detection (MAZIA et al., 1953), Toluidine Blue (O'BRIEN et al., 1964) was used to identify the richest portions of pectic compounds, lignin or cellulose, and finally fluoroglucionol (FOSTER, 1949) was used to detect lignin.
The images were recorded using an iPhone 6 cell phone camera manually attached to the photonic microscope (model Primo Star, Zeiss) to try to better capture the color obtained from each test. The scales were obtained from a micrometer slide.

\section{Scanning Electron Microscopy (SEM)}

The fixed pericarp samples were subjected to an increasing ethyl series (up to $99.5 \%$ alcohol) in order to remove all the water from the fragments. Thus, the samples were taken to the High Resolution Microscopy Multiuser Laboratory (LabMic) at the Federal University of Goiás $(U F G)$ to complete this dehydration process, where they were placed in a critical point chamber (CPDCritical Point Dryer) to complete drying these samples. Next, the samples were taken to the Regional Center for Technological Development and Innovation (CRTI) at the Federal University of Goiás, where the fragments were fixed on a brass sample holder and covered with carbon as a conductive material, and subsequently analyzed using a JEOL JSM-IT300 scanning electron microscope (SEM) under high vacuum in secondary electron detection mode for recording images. Specific compositional analyzes were also performed by the energy dispersion spectroscopy (EDS) technique with an Oxford Instruments X-MaxN X-ray detector coupled to a microscope, which enabled detecting the chemical elements which compose the fragments.

\section{Results and discussion}

P. cincinnata fruits showed little variation in the exocarp color in the pericarp over the 90 days observed in this study, with the color remaining in the range between light green and dark green in most of the analyzed samples; this demonstrates that the color variation is not indicative of fruit ripeness. In addition, a wrinkled appearance (Figure 1B) characteristic of dehydration, as well as the appearance of fungi and darkened areas (Figure 1D-E) were observed in a few fruits ( 1 every 15 days) from the $45^{\text {th }}$ day of storage, which was not enough to dispose the samples since the majority remained visually viable for consumption. In the open cross-sectioned fruit (Figure 2), it is possible to internally observe the apparent changes in the reduced pericarp thickness. This corroborates what was described by Carvalho (2019), who found a decrease of about $1.5 \mathrm{~mm}$ in the pericarp thickness of $P$. cincinnata fruit stored for 90 days at $5^{\circ} \mathrm{C}$. 

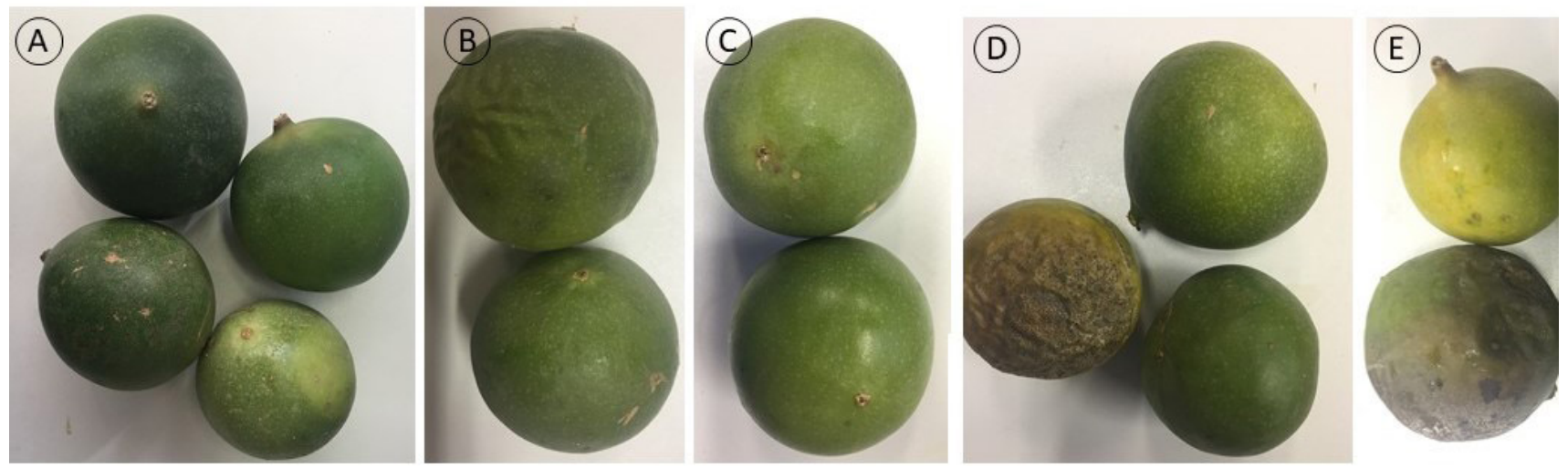

Figure 1- Morphological aspects and changes in the superficial appearance of Passiflora cincinnata Mast. fruits stored at $5^{\circ} \mathrm{C}$ for 90 days. A - Day 30; B - Day 45; C - Day 60; D - Day 75; E - Day 90.
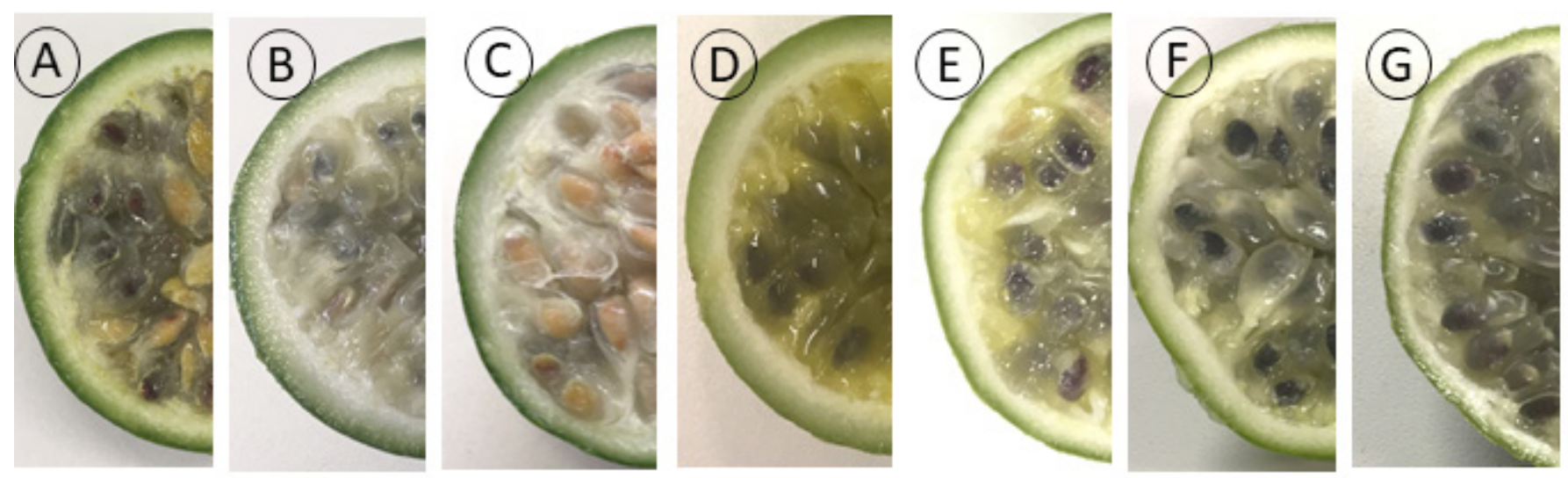

Figure 2. Internal appearance of Passiflora cincinnata Mast. Fruits stored at $5^{\circ} \mathrm{C}$ and apparent changes during 90 days of storage. A - Day 0; B - Day 15; C - Day 30; D - Day 45; E - Day 60; F - Day 75; G - Day 90.

Following the classification of Souza et al. (2006), the Passiflora cincinnata pericarp is composed of three anatomically distinct regions: exocarp, mesocarp and endocarp. The exocarp consists of a uni-stratified layer with trapezoidal to triangular cells, interspersed with cuticular flanges and covered by a thick lipid cuticle (Figures 3 and 7A-B). In addition, it was possible to observe a tector trichome (Figure $3 \mathrm{G}$ ), diverging from what was previously described for the fruit of this species, as there were previously no reports of the presence of trichomes (GURSKI, 2015). However, this structure was not frequently observed in the analyzes, which indicates that this trichome is not recurrent or is rare for the species.
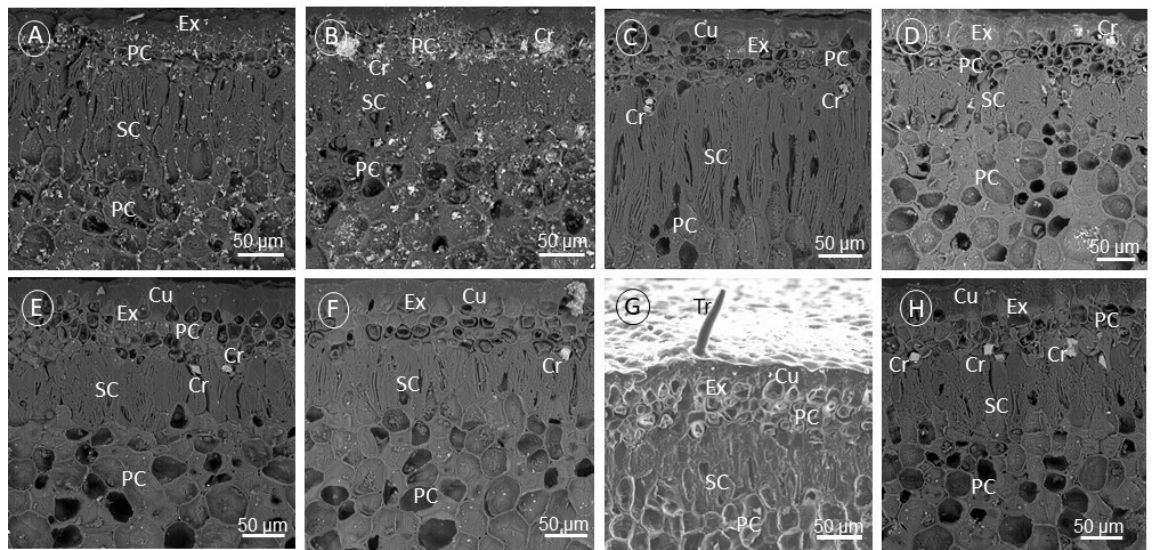

Figure 3. Exocarp and external mesocarp of Passiflora cincinnata Mast. A - Day 0; B - Day 15; C - Day 30; D - Day 45; E - Day 60; F - Day 75; G - Trichome in the fruit exocarp at day 75; H - Day 90. Legend: Cr, prismatic crystals; $\mathrm{Cu}$, cuticle; Ex, exocarp; PC, parenchymal cell; SC, sclerified cell; Tr, trichome. 
The mesocarp (Figures 3 and 4) was visualized in three distinct portions: external, medium and internal. Its external portion (Figure 3) consisted of 2-3 layers of parenchymal cells with thick anticline and periclinal walls, in addition to a quadrangular-oval shape; it was possible to observe idioblasts with prismatic crystals in the innermost layer which were distributed in a row along the entire mesocarp length. These crystals act as a diagnostic character for the species, since according to Gurski (2015), $P$. cincinnata was the only species which presented these structures when performing an ontogenesis of 10 passion fruit species.
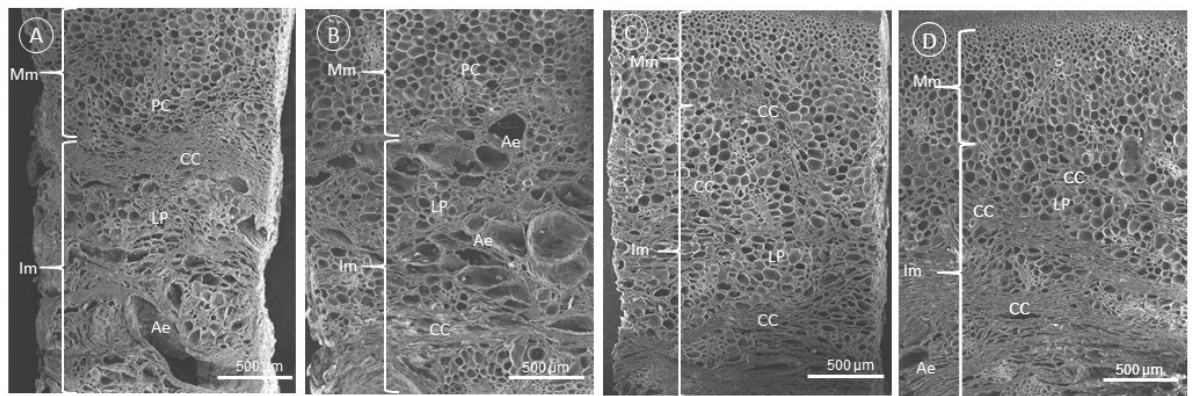

Figure 4. Middle and internal Passiflora cincinnata Mast. Mesocarp. A - Day 30; B - Day 45; C - Day 60; D - Day 75. Caption: Ae, aerenchyma; CC, compacted cells; En, Endocarp, Im, Internal mesocarp; LP, lax parenchyma; Mm, Middle Mesocarp; PC, parenchymal cell.

There were about 3-5 layers of lignified cells (Figure 7B) with an approximate elongated shape (Figure 3 ) in juxtaposition to these parenchymal cells, so that the pericarp of the analyzed fruits presented approximately the same number of layers in the external mesocarp in all the evaluation days; this is contrary to the initial expectations for this region, which predicted a variation in this number of layers.

The middle and internal mesocarps presented a similar composition to that described by Gurski (2015). The presence of several layers of rounded parenchymal cells were found in the middle mesocarp with a progressively increasing diameter from the outermost to the innermost layers. On the other hand, the internal mesocarp is formed by the lax parenchyma, consisting of larger parenchymal cells with large intercellular spaces (Figure 4), and by the aerenchyma, characterized as large spaces which appear in the middle of the mesocarp. It was also possible to detect air gaps in this region forming the aerenchyma (Figure 4A-B). In addition, several compacted parenchyma layers were observed, as well as vascular bundles located mainly in the innermost layers, although they also occur throughout the mesocarp (Figure 4). Druses with prismatic crystals were also identified in this region (Figure 6A).

It is also noticed that the fruits submitted to refrigeration presented similar changes in the mesocarp region, so that the middle mesocarp was formed by about 25 layers of cells until the $45^{\text {th }}$ day after harvest (Figure 4 A-B). However, the analyzes carried out after the $60^{\text {th }}$ day of storage demonstrated a change in the proportion between the middle and internal mesocarp, since the number of parenchymal cells in the internal mesocarp was reduced to about 15 layers due to the increase in layers which compose the lax parenchyma (Figure 4). According to Gurski (2015), the lax parenchyma is formed after a significant increase in the cell volume of the middle and internal mesocarp which undergo cell lysis, increasing the number and size of the intercellular spaces between the cells as a consequence of programmed cell death. Thus, there was an increase in the formation of intercellular spaces and the consequent addition of lax parenchyma layers over time and the continued maturation process. A consequence of this process was the reduced thickness and fresh mass of the peel during storage, as well as the progressive increase in water loss identified in these fruits (CARVALHO, 2019).

The innermost region of the fruit (the endorcarp) was uni-stratified and composed of approximate quadrangular cells (Figure 5) with cell walls rich in pectic compounds (Figure 7F). This description is similar to that found in other passion fruit species, such as Passiflora coccinea Aubl., Passiflora edmundoi Sacco and Passiflora elegans Mast. (GURSKI, 2015). 

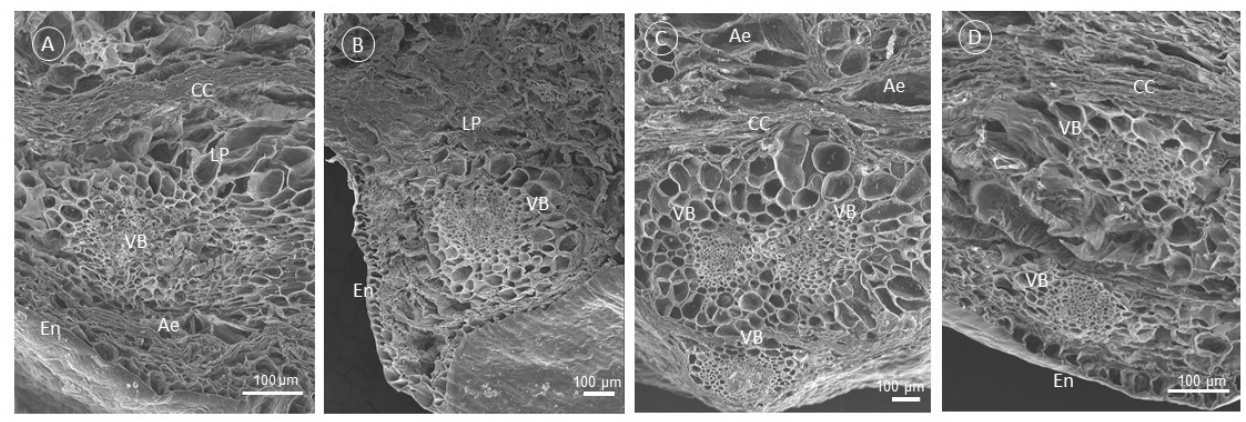

Figure 5. Vascular bundles in the internal mesocarp and endocarp of the Passiflora cincinnata Mast. pericarp: A Day 15; B - Day 30; C - Day 45; D - Day 75. Caption: Ae, aerenchyma; CC, compacted cells; En, Endocarp, LP, lax parenchyma; VB, Vascular bundles.
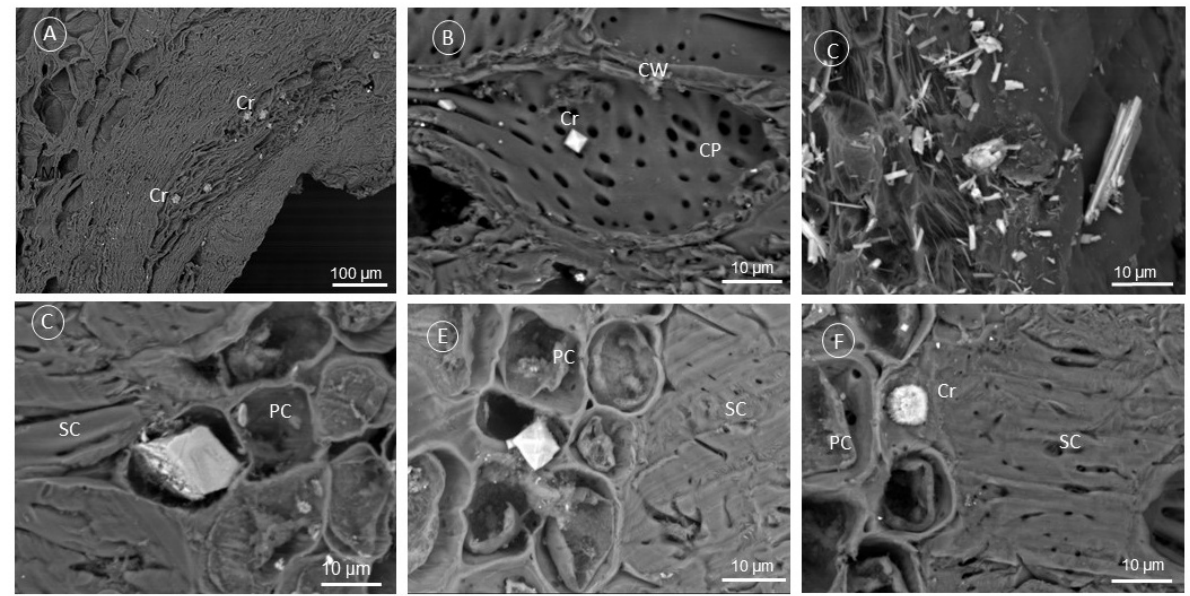

Figure 6. Crystalline structures in the Passiflora cincinnata Mast. Mesocarp: A - Prismatic crystals and druses in the vascular bundle; B - Prismatic crystal and points in the sclerified cell; C - Raphide and acicular crystals; D-F, Druses. Legend: Cr, prismatic crystals; CW, cell wall; CP, cellular points; PC, parenchymal cell; SC, sclerified cell.
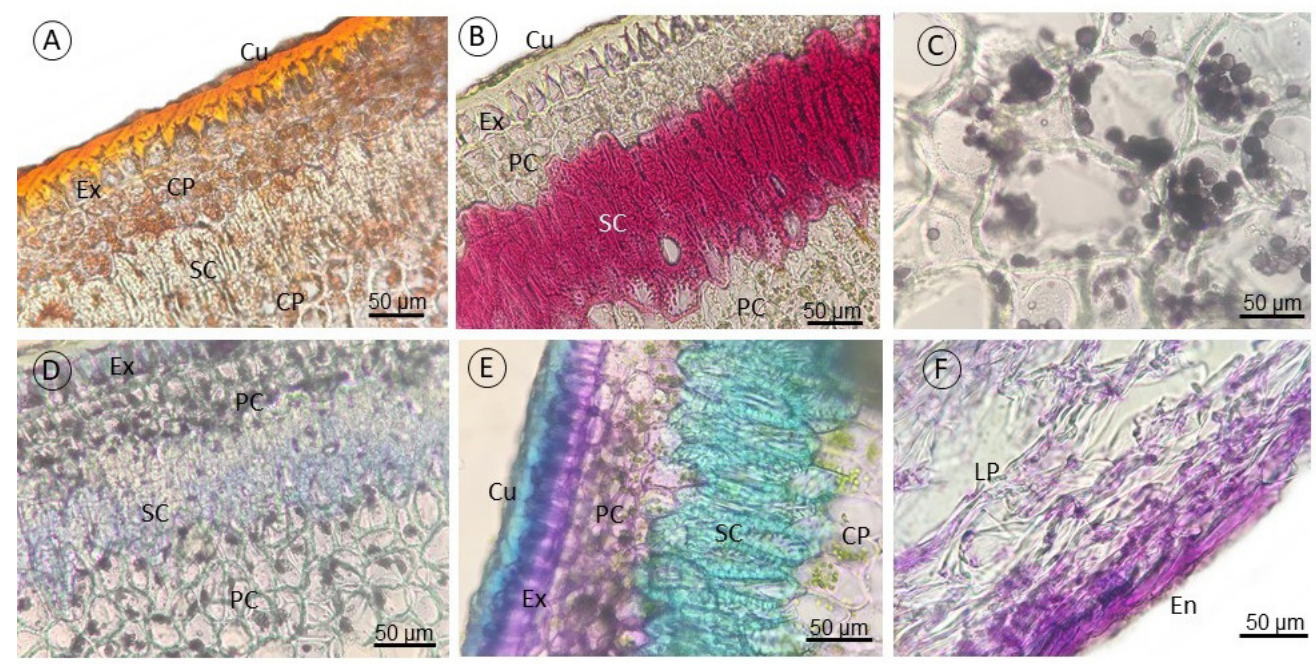

Figure 7. Histochemical tests on the Passiflora cincinnata Mast. Pericarp: A - Sudan III test showing lipids in the exocarp cuticle and in the form of vesicles within the mesocarp cells; B - Fluoroglucionol indicating the presence of lignin in the sclerified cells of the mesocarp; C - Lugol test showing starch in the mesocarp parenchyma; D Bromophenol mercury blue detecting protein bodies inside mesocarp cells; E - Toluidine blue showing cellulosic wall cells in the exocarp and sclerified cells in the mesocarp; F - Toluidine blue test showing pectic compounds in endocarp cells. Legend: Cu, cuticle; En, Endocarp; Ex, exocarp; LP, lax parenchyma; PC, parenchymal cell; SC, sclerified cell. 
No divergent results were detected between the samples regarding the histochemical tests, since these qualitative tests indicated the presence of the same substances in all analyzes. Thus, in addition to the presence of a lipid cuticle (Figure 7A) and sclerenchyma (Figure 7B) in all analyzed samples, lipid vesicles (Figure 7A), starch (Figure 7C) and proteins (Figure 7D) were identified in the mesocarpal cells. According to Evert (2006), these vesicles must act as a reserve for these substances in the mesocarp. In addition, it is important to note that most cells in the pericarp had a cellulose-rich pectin wall composition, with the exception of sclerenchyma cells (Figure 7 E-F). Mucilage and pectic polysaccharides make up so-called soluble fibers, which may result in delayed glucose absorption, reduced blood cholesterol, and decreased gastric emptying when consuming them, among other benefits (CATALANI et al., 2003). Moreover, pectin promotes increased viscosity in the industrial sector and works as a stabilizing and protective colloid in food and beverages (CATALANI et al., 2003). It is worth mentioning that Pita (2012) observed that passion fruit peel flour had a higher pectin content in relation to the yellow passion fruit flour, which indicates the potential of using pericarp as a residue to be used in manufacturing foods.

It was possible to observe a large amount of raphide and acicular crystals, druses and prismatic crystals throughout the pericarp (Figure 6). Like the prismatic crystals of the internal mesocarp, these structures stand out due to the presence of calcium, which was detected close to oxygen in the EDS analyzes (Figures 8A and 8E-F). According to Kikuchi et al. (2007), this proximity suggests the existence of a calcium compound, possibly oxalate. These crystals can serve as a strong calcium collector, controlling the excess of this element and protecting the pericarp (FRANCESCHI and NAKATA, 2005; MILANI, 2014). Furthermore, a reduction in the presence of these structures was observed during the storage period, which according to Fagundes (2009) may indicate that the calcium was used during the fruit ripening or redirected to other structures, promoting its decline or disappearance in the ripe fruit.
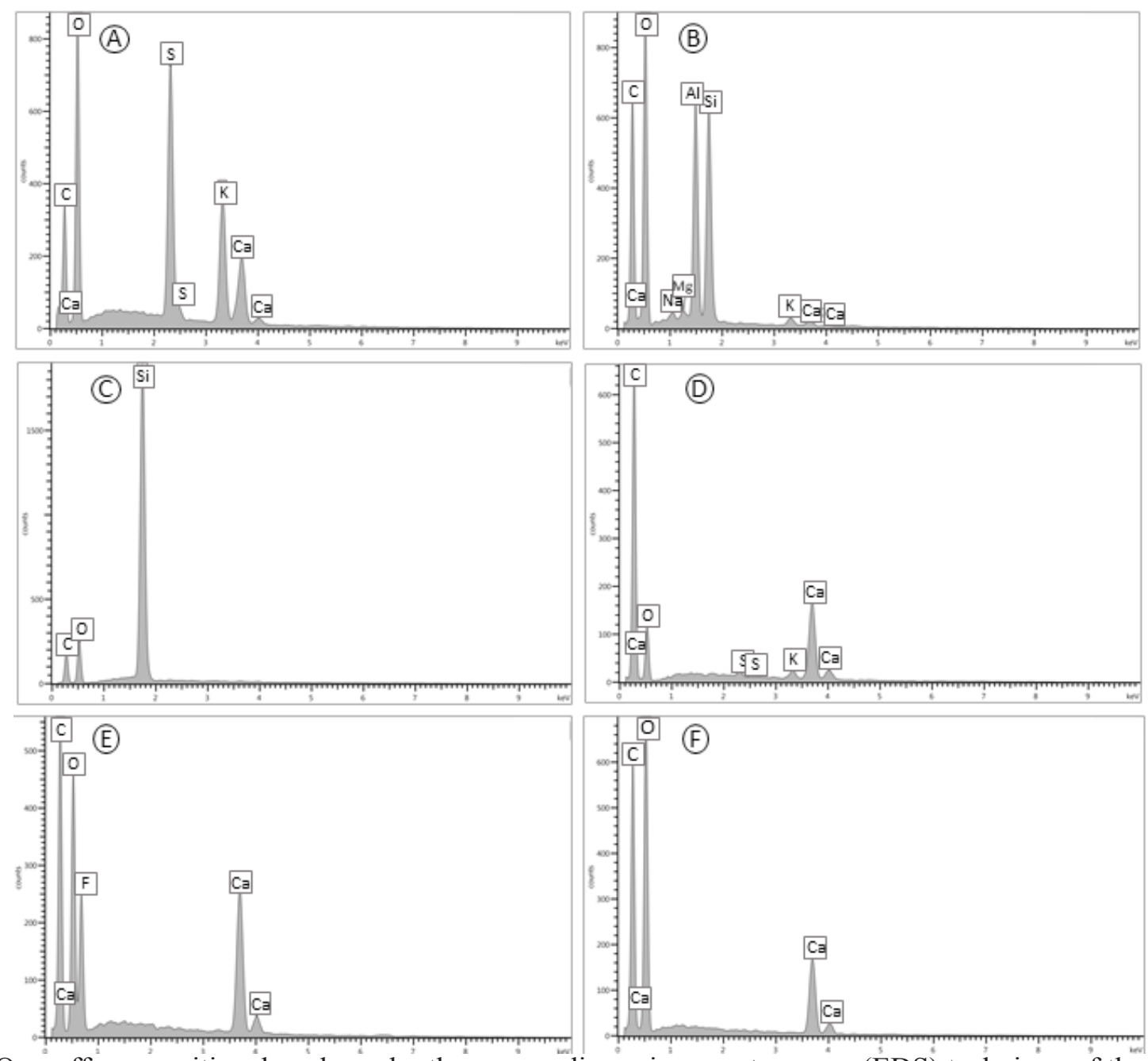

Figure 8. One-off compositional analyzes by the energy dispersion spectroscopy (EDS) technique of the Passiflora cincinnata Mast. Pericarp: A - Prismatic crystal identified on the day 15; B - Silica crystal and minerals in the sample on the day 30; C - Silica crystal identified on day 45; D - Crystal identified on day 45; E - Prismatic crystal in the sample on day 75; F - Prismatic crystal identified in the sample on day 90. 
In addition, EDS analyzes enabled identifying several silica crystals and silica grains scattered throughout the mesocarp (Figure 8B-C). The presence of silica in plant organs is able to protect the plant from biotic and abiotic stress, since this element contributes to controlling diseases caused by fungi and bacteria (MA and YAMAJI, 2006). According to Junqueira (2005), the presence of silica structures and oxalate crystals, as observed in P. cincinnata, can support the resistance of this species against diseases and pests.

The analysis also revealed the predominant presence of oxygen $(\mathrm{O})$ and carbon $(\mathrm{C})$ in the cell walls of the mesocarp. In addition, macronutrients $(\mathrm{P}, \mathrm{K}, \mathrm{Ca}, \mathrm{Mg}$, $\mathrm{S}$ and $\mathrm{P})$ and micronutrients $(\mathrm{Cl}, \mathrm{Fe})$ were also identified in the composition of the crystalline structures (Figure 8), with the most recurrent elements in all analyzed samples being $\mathrm{C}$ and $\mathrm{O}$, as well as sulfur $(\mathrm{S})$, calcium $(\mathrm{Ca})$ and potassium $(\mathrm{K})$. It is also worth mentioning that it was not possible to assess the quantitative variation of the mineral elements mentioned above over the 90 days of analysis since the EDS assessment is only qualitative. Thus, only the elements identified in this analysis were considered.

Despite the benefits already presented, it is important to highlight that consumption of the plant can have a negative impact on human health due to the performance of calcium oxalate crystalline structures in the plant's biotic defense acting as an antinutrient, toxin and in the formation of kidney stones (FRANCESCHI and NAKATA, 2005). As the $P$. cincinnata pericarp presented many of these structures, especially in the first 15 days post-harvest, further studies are needed to quantify oxalate in the peels of this species, as well as to verify if there is any side effect from consuming food produced from it, since it was found that the passion fruit pericarp could be used in the food industry.

\section{Conclusions}

The main structural changes observed in the postharvest period of the $P$. cincinnata pericarp were a reduction in the number of raphide in the mesocarp region over time, as well as an increase in lax parenchyma layers due to the appearance of new cell spaces. These changes reflect physiological changes which also occur during senescence, such as water loss and the metabolism of pericarp constituents. In addition, crystalline structures such as raphide, acicular, druse and silica crystals found in this fruit have a diagnostic character for the species.

It is worth mentioning that storage at $5^{\circ} \mathrm{C}$ may have delayed the speed of the morphophysiological changes which naturally occur in the post-harvest period, which may explain the reason why many anatomical changes were not observed in these fruits during the analysis intervals.

\section{Acknowledgements}

To the Coordenação de Aperfeiçoamento Pessoal de Ensino Superior - CAPES for granting the Master's scholarship, to LabMic for preparing samples at a critical point, and to $C R T I$ for the images and SEM analyzes.

\section{References}

ARAÚJO, F.P. Caracterização da variabilidade morfoagronômica de maracujazeiro (Passiflora cincinnata Mast.) no Semi-árido. 2007. Tese (Doutorado) - Faculdade de Ciências Agronômicas, Universidade Estadual Paulista, Botucatu, 2007.

ARAÚJO, F.P.; SILVA, N.; QUEIROZ, M.A. Divergência genética entre acessos de Passiflora cincinnata Mast com base em descritores morfoagronômicos. Revista Brasileira de Fruticultura, Jaboticabal, v.30, n.3, p.723730, 2008.

AZOUBEL, P.M.; ARAÚJO, A.J.B.; OLIVEIRA, S.B.; AMORIM, M.R. Restructuring Passiflora cincinnata fruit pulp: influence of hydrocolloids. Food Science and Technology, Campinas, v.31, n.1, p.160-166, 2011.

CARVALHO, C.R.V. Variação dos aspectos fisiológicos e anatômicos do fruto de Passiflora cincinnata Mast. armazenado sob refrigeração. 2019. Dissertação (Mestrado em Ciências Ambientais) - Universidade Federal do Oeste da Bahia, Barreiras, 2019.

CATALANI, L.A.; KANG, É.M.S.; DIAS, M.C.G.; MACULEVICIUS, J. Fibras alimentares. Revista Brasileira de Nutrição Clínica, São Paulo, v.18, n.4, p.178-182, 2003.

CERVI, A.C. Passifloraceae do Brasil. Estudo do gênero Passiflora L., subgênero Passiflora. Fontqueria, Madrid, v.45, p. 1-92, 1997.

COSTA, G.M. Estudo químico de espécies brasileiras e colombianas do gênero Passiflora. 2013. Tese (Doutorado em Farmácia) - Centro de Ciências da Saúde Universidade Federal de Santa Catarina, Florianópolis, 2013.

DHAWAN, K.; DHAWAN, S.; SHARMA, A. Passiflora: a review update. Journal of Ethnopharmacology, New York, v.94, p.1-23, 2004. 
ESTEVAM, C.S.; LIMA, C.A.; SANTOS, J.L.; MARCHIORO, M.; ARAÚJO, B.S.; CORRÊA, C.B.; SANTOS, C.M.C.; SANTANA, I.S.; ARAUJO, S.S. Glycemic regulation and cytotoxic characteristics of the ethyl acetate fraction from Passiflora cincinnata Mast Leaves. Preprints, London, 2017. Available from: doi: 10.20944/preprints 201708.0060.v1.

EVERT, R.F. Esau's plant anatomy: meristems, cells, and tissues of the plant body: their structure, function, and development. $3^{\text {rd }}$ ed. Hoboken: Wiley e Sons, 2006.

FAGUNDES, N.F. Morfo-anatomia, ontogenia e histoquímica de fruto em Bromeliaceae Juss. 2009. Dissertação (Mestrado em Botânica) - Universidade Federal do Rio Grande do Sul, Porto Alegre, 2009.

FOSTER, A.S. Pratical plant anatomy. Princeton: D Van Nostrand Company, 1949.

FRANCESCHI, V.R.; NAKATA, P.A. Calcium oxalate in plants: formation and function. Annual Review of Plant Biology, Palo Alto, v.56, p.41-71, 2005.

FURR, M.; MAHLBERG, P.G. Histochemical analyses of laticifers and glandular trichomes in Cannabis sativa. Journal of Natural Products, Washington, v.44, n.2, p.153-159, 1981.

GABE, M. Techniques histologiques. Paris: Masson e Cie, 1968.

GAZOLA, A.C. Avaliação química e neurofarmacológica de espécies de Passiflora da América do Sul. 2014. Tese (Doutorado em Farmácia) - Centro de Ciências da Saúde, Universidade Federal de Santa Catarina, Florianópolis, 2014.

GURSKI, C. Anatomia de frutos e sementes de espécies de Passiflora L. - subgêneros Decaloba (DC.) Rchb. e Passiflora L. (Passifloraceae). 2015. Tese (Doutorado em Biologia Vegetal) - Instituto de Biologia, Universidade Estadual de Campinas, Campinas, 2015.

ISHIMOTO, F.Y.; HARADA, A.I.; BRANCO, I.G.; CONCEIÇÃO, W.A.S.; COUTINHO, M.R. Aproveitamento alternativo da casca do maracujá- amarelo (Passiflora edulis f. var. flavicarpa Deg.) para produção de biscoitos. Revista Ciências Exatas e Naturais, Guarapuava, v.9, n. 2, p.279-292, 2007.

JENSEN, W.A. Botanical histochemistry, principles and practice. San Francisco: WH Freeman, 1962.
JOHANSEN, D.A. Plant microtechnique. New York: McGraw-Hill Book, 1940.

JUNQUEIRA, N.T.V.; FALEIRO, F.G.; BERNACCI, L.; BRAGA, M.F.; PEIXOTO, J.R. Potencial de espécies silvestres de maracujazeiro como fonte de resistência a doenças. In: FALEIRO, F.G.; JUNQUEIRA, N.T.V.; BRAGA, M.F. Maracujá: germoplasma e melhoramento genético. Planaltina, DF: Embrapa Cerrados, 2005. p.81108 .

KIKUCHI, T.Y.P.; POTIGUARA, R.C.V.; SANTOS, P.P. Caracterização histoquímica e ultra-estrutural do estipe de Socratea exorrhiza (Mart.) H. Wendl. (Arecaceae). Boletim do Museu Paraense Emílio Goeldi. Ciências Humanas, Belém, v.2, n.2, p.61-68, 2007.

LIMA, C.S.M.; SEVERO, J.; ANDRADE, S.B.; AFFONSO, L.B.; ROMBALDI, C.V.; RUFATO, A.D.R. Qualidade pós-colheita de Physalis sob temperatura ambiente e refrigeração. Revista Ceres, Viçosa, MG, v.60, n.3, p.311-317, 2013.

O'BRIEN, T.P.; FEDER, N.; MCCULLY, M.E. Polychromatic staining of plant cell walls by toluidine blue O. Protoplasma, Wien, v.59, p. 367-373, 1964.

OLIVEIRA, F. Caracterização pós-colheita de frutos e atividade biológica de extrato foliar e frações obtidos de Passiflora cincinnata Mast. (Passifloraceae). 2014. Dissertação (Mestrado em Ciências Ambientais) - Universidade Federal do Oeste da Bahia, Barreiras, 2014.

OLIVEIRA, L.F.; NASCIMENTO, M.R.F.; BORGES, S.V.; RIBEIRO, P.C.N.; RUBACK, V.R. Aproveitamento alternativo da casca do maracujá-amarelo (Passiflora edulis F. flavicarpa) para produção de doce em calda. Ciência e Tecnologia de Alimentos, Campinas, v.22, n.3, p.259-262, 2002.

OLIVEIRA, J.C.; RUGGIERO, C. Espécies de maracujá com potencial agronômico. In: FALEIRO, F.G.; JUNQUEIRA, N.T.V.; BRAGA, M.F. Maracujá: germoplasma e melhoramento genético. Planaltina: Embrapa Cerrados, 2005. p.143-158.

MA, J.F.; YAMAJI, N. Silicon uptake and accumulation in higher plants. Trends in Plant Science, Amsterdam, v.11, n.8, p.392-397, 2006. 
MAZIA, D.; BREWER, P.A.; ALFERT, M. The cytochemistry staining and measurement of protein with mercuric bromophenol blue. Biological Bulletin, Lancaster, v.104, n.1, p.57-67, 1953.

MDITSHWA, A.; MAGWAZA, L.S.; TESFAY, S.Z.; MBILI, N. Postharvest quality and composition of organically and conventionally produced fruits: A review. Scientia Horticulturae, New York, v.216, p.148-159, 2017.

MILANI, J. F. Ontogenia de frutos e sementes de quatro espécies de Passiflora (Passifloraceae - Subgênero Decaloba (DC.) Rchb. Seção Xerogona (Raf.) Killip). 2014. Tese (Doutorado em Biologia Vegetal) - Instituto de Biologia, Universidade Estadual de Campinas, 2014.

MONTERO, D.A.V.; MARQUES, M.O.M.; MELETTI, L.M.M.; KAMPEN, M.H.V.; POLOZZI, S.C. Floral scent of brazilian Passiflora: five species analised by dynamic headspace. Anais da Academia Brasileira de Ciências, Rio de Janeiro, v.88, n.3, p. 1191-1200, 2016.

NASCIMENTO, E.M.G.C., ASCHERI, J.L.R., CARVALHO, C.W.P., GALDEANO, M.C. Benefícios e perigos do aproveitamento da casca de maracujá (Passiflora edulis) como ingrediente na produção de alimentos. Revista Instituto Adolfo Lutz, São Paulo, v.72, n.13, p.1-11, 2013.

NUNES, T.S. A família Passifloraceae no estado da Bahia, Brasil. 2002. Dissertação (Mestrado em Botânica) - Universidade Estadual de Feira de Santana, Feira de Santana, 2002.

PEIXOTO, M. Problemas e perspectivas do maracujá ornamental. In: FALEIRO, F.G.; JUNQUEIRA, N.T.V.; BRAGA, M.F. Maracujá: germoplasma e melhoramento genético. Planaltina - Distrito Federal: Embrapa Cerrados. 2005. p.457-463.
PITA, J.S.L. Caracterização físico-química e nutricional da polpa e farinha da casca de maracujazeiros do mato e amarelo. 2012. Dissertação (Mestrado em Engenharia de Alimentos) - Universidade Estadual do Sudoeste da Bahia, Itapetinga, 2012.

ROCHA, R.H.C.; SILVA, E.O.; SALOMÃO, L.C.C.; VENTRELLA, M.C. Caracterização do melão gália no ponto de colheita. Revista Brasileira de Fruticultura, Jaboticabal, v.32, n.2, p. 375-385, 2010.

SANTOS, T.C.; JÚNIOR, J.E.N.; PRATA, A.P.N. Frutos da Caatinga de Sergipe utilizados na alimentação humana. Scientia Plena, v.8. n.4, 2012.

SIEBRA, A.L.A.; OLIVEIRA, L.R.; MARTINS, A.O.P.B.; SIEBRA, D.C.; ALBUQUERQUE, R.S.; LEMOS, I.C.S.; DELMONDES, G.A.; TINTINO, S.R.; FIGUEREDO, F.G.; COSTA, J.G.M.; COUTINHO, H.D.M.; MENEZES, I.R.A.; FELIPE, C.F.B.; KERNTOPF. Potentiation of antibiotic activity by Passiflora cincinnata Mast. front of strains Staphylococcus aureus and Escherichia coli. Saudi Journal of Biological Sciences, Amsterdam, v.25, p.37-43, 2018.

SILVA, M.R.; LACERDA, D.B.C.L.; SANTOS, G.G.; MARTINS, D.M.O. Caracterização química de frutos nativos do cerrado. Ciência Rural, Santa Maria, v.38, n.6, p.1790-1783, 2008.

SOUZA, M.W.S.; FERREIRA, T.B.O.; VIEIRA, I.F.R. Composição centesimal e propriedades funcionais tecnológicas da farinha da casca do maracujá. Alimentos e Nutrição, Araraquara, v.19, n.1, p. 33-36, 2008.

SOUZA, L.A; MOSCHETA, I.S.; MOURÃO, K.S. In: APPEZZATO-DA-GLÓRIA, B.; CARMELLHOGUERREIRO, S.M. Anatomia vegetal. 2.ed. Viçosa: Ed. UFV, 2006. 24p.

ZERAIK, M.L.; PEREIRA, C.A.M.; ZUIN, V.G.; YARIWAKE, J.H. Maracujá: um alimento funcional? Revista Brasileira de Farmacognosia, Curitiba, v.20, n.3, p.459-471, 2010. 